\title{
EURO EFFECT ON TRADE IN FINAL, INTERMEDIATE AND CAPITAL GOODS
}

\author{
INMACULADA MARTÍNEZ-ZARZOSO ${ }^{1,2, *, \dagger}$ and FLORIAN JOHANNSEN ${ }^{2}$ \\ ${ }^{1}$ Georg-August Universität Göttingen, Germany \\ ${ }^{2}$ Universitat Jaume I, Spain
}

\begin{abstract}
The aim of this paper is to provide fresh evidence on the effect of the adoption of the euro on exports of different types of goods. The novelty with respect to previous research is threefold. First, disaggregated trade data are used to allow for heterogeneous effects for final intermediate and capital goods. Second, we distinguish between the euro effect on the extensive and the intensive margins of trade. Finally, we estimate the impact of the Euro adoption controlling for exchange rate volatility, exchange rate movements and EU membership. This allows us to disentangle the effect of a common currency beyond the elimination of trade barriers and of any variation in the exchange rate. The main results indicate that the impact of the Euro on trade values (intensive margin) is around 9\% for intermediates, $7 \%$ for final goods and it is negative for capital goods. Interestingly, the Euro effects on the extensive margin of trade are found to be negative and significant for the three types of goods, pointing to increasing specialization. Copyright (C) 2016 John Wiley \& Sons, Ltd.
\end{abstract}

Received 28 December 2015; Revised 26 July 2016; Accepted 11 September 2016

JEL CODE: F15; F36

KEY WORDS: gravity model; euro effect; intermediate products; capital goods; final goods; bilateral trade

\section{INTRODUCTION}

The introduction of the Euro and the creation of the Euro zone in the late 1990s, associated with the abolition of several European currencies, led to an avid debate among economists concerning the effect of the single-currency adoption on trade. More recently, the global financial crisis, the catalyst of the debt crises and the massive central bank interventions in Europe and the U.S. increased exchange rate volatility again and brought the topic back on the agenda.

In light of the recent events, especially the case of the European Union and the Euro adoption is worth a second glance. The question whether joining a currency union boosts trade significantly is very relevant for many Central and Eastern European countries. The fact that countries like Poland have postponed their accession to the Euro is linked to the idea that the expected positive trade effects on of joining a currency union might eventually turn into negative economic effects.

The new trade theory that incorporates firm heterogeneity into the modelling framework and highlights the importance of differences in productivity between firms in explaining trade gains (Melitz, 2003), identifies two channels through with a common currency could increase trade. First, through an increase in the average value of the transactions, the so-called intensive margin of trade, this is mainly linked to a decrease in variable trade costs. Second, through an increase in the number of varieties traded, namely the extensive margin of trade related to a decrease in fixed cost. Both transmission channels could be relevant to explain the Euro effect. However, it

*Correspondence to: Inmaculada Martínez-Zarzoso, Chair of Economic Theory and Development Economics, Platz der Göttinger Sieben 3, 37073 Göttingen, Germany.

$\dagger$ E-mail: imartin@uni-goettingen.de 
has to be mentioned that joining a currency union also imply that country members renounce to have an independent monetary policy and hence are unable to implement competitive devaluations as a response to asymmetric shocks.

The empirical literature on the relationship between currency unions and trade indicates that in general having a common currency fosters trade. While early studies found large effects and trade to triple (Rose, 2000; Frankel and Rose, 2002; Glick and Rose, 2002), most recent studies reported only moderate trade increases of around 5-30\% on average (Flam and Nordström, 2007; Baldwin and Di Nino, 2006; Eicher and Henn, 2011; Glick and Rose, 2002). It is also worth mentioned that a few authors reported instead non-significant Euro effects on trade (e.g. Berger and Nitsch, 2008; Santos Silva and Tenreyro, 2010). ${ }^{1}$ The usual argument supporting positive trade effects from the formation of currency unions is that a currency union goes beyond the mere elimination of exchange rate variability and lowers transaction costs to a greater extent. ${ }^{2}$ However, the effects might differ by type of product traded, this issue been recently investigated by Badinger and Türkcan (2014). ${ }^{3}$ The authors find that the Euro adoption increase trade on average, but the main effect materializes through the intensive margin, while the Euro effect on the extensive margin is found to be negative. The authors highlight the differences obtained for harmonized system (HS) 2-digit products concerning the euro effect on trade. They base their explanation in the recent trade theory models and their predictions concerning the link between the elasticity of substitution and reductions in trade costs. Products with a high elasticity of substitution could be more affected by a reduction in trade costs than other products. We go a step forwards and group goods according to its final use into capital, intermediate and final goods; and ask the question whether the effects differ for each type, because these three groups differ significantly in terms of contracting.

In this paper, we aim to provide further empirical evidence on the relationship between currency unions and trade incorporating two main novelties with respect to previous research. First, disaggregated trade data at monthly frequency are used to deal with differences among industries and between capital, final and intermediate goods. Second, we consider the presence of zero trade flows and distinguish between extensive and intensive margins of trade. In addition, the simultaneous incorporation into the model of exchange rate volatility, integration and currency effects allows us to disentangle the effect of a common currency beyond the elimination of any variation in the exchange rate with other members and beyond the elimination of trade barriers. Furthermore, the developments of the past years with the financial crisis and the EU enlargement to the East are taken into account, yielding additional findings and policy implications. Almost all empirical studies on the Euro effect are based on the gravity model of trade, ${ }^{4}$ and this is also the chosen framework in this paper. We estimate an augmented gravity model of trade for a sample of 35 countries over the period from January 1996 to December 2010.

We argue that previous studies investigating the Euro effect in the early years of the Eurozone could be biassed because of the boom in imports from other Eurozone members to the periphery countries. This boom, as we know today, was partly caused by consumption and housing bubbles that led to the European 'debt crisis'. Hence, trade effects for the early years, especially for final goods, could have been overestimated.

The rest of the paper is structured as follows. Section 2 describes the empirical strategy and several issues related to the econometric estimation. Section 3 presents the main results, and, finally, section 4 concludes with a summary of the main findings and some policy implications.

\section{EMPIRICAL STRATEGY}

The empirical analysis is based on the standard gravity model of trade that was first developed by Tinbergen (1962). It is based on Newton's law of universal gravitation, according to which planets are mutually attracted in proportion to their physical mass and proximity. Transferred to the world of trade, physical mass is replaced with economic mass which is usually measured as GDP. Thus, trade between two countries is modelled as a function of their 'economic mass' and the distance between them and has the following form:

$$
X_{i j}=G A_{i} B_{j} \varphi_{i j}
$$

where $\mathrm{X}_{\mathrm{ij}}$ denotes the monetary value of exports from $i$ to $j, A_{i}$ and $B_{j}$ denote exporter and importer specific factors that influence production capacity in country $i$ and demand in country $j$, respectively. $G$ is a variable such as the 
level of world trade liberalization, which does not depend on country-specific factors. Finally, $\phi_{i j}$ represents the ease of exporter $i$ to access to market $j$; it is the inverse of bilateral trade costs.

\subsection{Estimation issues}

Numerous contributions and further developments of the gravity model of trade have validated and enriched the model in the past two decades. In particular, the work of Anderson and Van Wincoop (2003) has been very influential. They emphasize that in a theoretically founded gravity model, trade costs must also enter in relative terms with respect to the rest of the world in order to model a country overall 'resistance' to trade. A way to do this is by introducing 'multilateral trade-resistance' (MTR) factors into the gravity framework. The basic idea is that two countries tend to trade less with each other when they are surrounded by big economies than when they are surrounded by water, mountains or deserts. We are specifying MTR using country-year dummies that control for time-varying exporter and importer effects. Because GDP variables for exporter and importer, usually employed in the gravity model to measure economic mass, vary only by year and country, we use the log of the cross-product of GDPs.

Another important issue, especially when dealing with sectoral trade flows or trade between small countries, is the presence of zero trade flows. While previous trade theories were not capable of explaining the existence of zeros in trade flows, the monopolistic-competition model of heterogeneous firms developed by Melitz (2003) explains their existence with differences in productivity between firms. Helpman et al. (2008) specified a model that allows controlling for zero trade flows using a two-stage procedure that incorporates firm heterogeneity into the modelling framework.

Alternative ways to retain the zero trade flows have been proposed in the related literature. The most popular one is to use the Pseudo Poisson maximum likelihood (PPML) estimation (Santos Silva and Tenreyo, 2006) the implicit assumption of which is that that zeros are the result of rounding errors and hence missing observations are wrongly recorded at zero (Martínez-Zarzoso, 2013). The PPML method estimates the gravity model in its original multiplicative form, permitting the inclusion of zeros, and also allowing for a more flexible distribution of the error term. However, zeros can also be the result of firms' decision not to export to a given destination, in particular when dealing with sectoral trade data, as in this paper. In this case, Helpman et al. (2008) suggest taking a Heckman approach, which involves two steps. In the first stage, the probability of firms' entering into an export market (extensive margin), which is an unobserved variable in the standard gravity equation, is modelled using a Probit model, and in the second, the gravity equation is estimated on the positive trade flows including two additional regressors: a correction for selection bias and a correction for firm heterogeneity. The main difficulty in this approach is to find an exclusion variable for the probit model (selection equation) that is exogenous to the trade value. We solve this difficulty by using a corruption indicator (see below).

It is important to notice that although this method deals with zeros, its main aim is to remove the effect of the extensive margin in order to isolate intensive margin effects (Head and Mayer, 2014).

The first-stage Probit model is given by:

$$
\rho_{i j}=\operatorname{Pr}\left(T_{i j}=1\right)=\Theta\left(y_{0}+v_{i}+\sigma_{j}+\kappa V C_{i j}+\zeta F C_{i j}\right)
$$

where the probability of exports from $\mathrm{i}$ to $\mathrm{j}$ depends on importer and exporter dummies $v_{\mathrm{i}}$ and $\sigma_{\mathrm{j}}$, and ons bilateral variable representing variable export costs, $\mathrm{VC}_{\mathrm{ij}}$, and fixed costs of entry, $\mathrm{FC}_{\mathrm{ij}}$.

In the second stage, the determinants of trade flows are estimated using an augmented version of the gravity equation where two elements of the first stage regression (the predicted value and the Inverse Mill's Ratio, IMR) are used to control for firm heterogeneity and sample selection bias. Following this approach, the resulting equation then is:

$$
X_{i j}=\beta_{0}+I_{i}+I_{j}+\kappa V C_{i j}+\ln \left(e^{\left.\delta\left(z_{i j}+\eta_{i j}\right)-1\right)+\beta_{\eta} \eta_{i j}+e_{i j}}\right.
$$

where $X_{i j}$, the dependent variable, denotes trade flows between $i$ and $j$ and $I_{i}$ and $I_{j}$ denote exporter- and importerspecific factors. The term in brackets is the share of firms that export to $\mathrm{j}$, with $\mathrm{z}_{\mathrm{ij}}$ representing the predicted extensive margin obtained from the first stage and $\eta_{\mathrm{ij}}$ the IMR. 
As mentioned above, requirement of this approach is to find an exclusion restriction. A variable that enters the first stage and affects the probability to export but has no significant impact on the trade value is needed to estimate the model.

Most authors used a dummy variable that takes the value of one when countries share the same religion and zero otherwise as the excluded variable (Helpman et al., 2008). In the European context, we do not consider this as a good choice, as all countries share a Christian heritage and only some of their main trading partners differ in this respect. ${ }^{5}$ In addition, the main religion of a specific country does usually not vary over time. Hence, in the case of the EU members, we assume the cross product of the time varying measure of corruption for exporter and importer could be an appropriate exclusion variable. The channel through which it affects trade is by rising insecurity and associated extra fixed costs for the exporting firm stemming from a higher probability of authorities or criminals trying to extort bribes in their homeland or export destination (Crozet et al., 2008).

For firms in countries with very low levels of corruption, this can be seen as a serious obstacle to start exporting as those countries are usually not used to this practices. Nevertheless, corruption could also have positive effects on trade. For instance, corrupt officials might allow firms to export or import even if their products do not meet technical, ethical, quality or safety standards. In overregulated countries, this could lower fixed trade costs significantly (Rose-Ackerman, 1999). Either way, by influencing fixed-costs rather than variable costs, corruption can be thought of as an additional factor influencing the decision to trade, which is not expected to have a significant impact on the value of trade once firms learn how to operate in a corrupt environment.

An additional possible source of estimation bias is the endogeneity of the decision to join a currency union. Frankel (2008) argues that endogeneity was not responsible for the extremely high estimates of early studies investigating currency union effects on trade. He presents estimates of similar magnitude to those found by a large number of early studies for the CFA zone, whose members have not decided to peg their currency to the Euro, but did so after France joined the Euro zone. This peg was not accompanied by other steps of integration, which may have boosted trade. It stands for an interesting natural experiment as the currency decision can be seen as exogenous.

In our case, we assume endogeneity of the currency decision is not a serious issue as past integration steps for Euro zone members are controlled for with a dummy for membership in the European Union (EU). Besides the common currency, Eurozone members have the same degree of trade facilitating integration as members of the EU. We assume that the decision to join the Euro zone is a political decision that is mostly driven by other factors different from those influencing the value of trade. ${ }^{6}$

\subsection{DATA, SOURCES AND VARIABLE DESCRIPTION}

The dataset consists on monthly bilateral exports for 35 countries over the period from January 1996 to December 2010. The countries included are the EU-27 countries and their mayor trading partners (Table A.1). ${ }^{7}$

The dependent variable is nominal monthly bilateral trade disaggregated according to the classification by Broad Economic Activities (BEC) from Eurostat. ${ }^{8}$ Because Eurostat does not contain data on bilateral trade between two non-EU members, data on trade flows between countries that are not members of the EU is not recorded. Nevertheless, the share of total EU-27 trade covered by our sample is well over $80 \%$ (Table A.1).

We assign the BEC sectors to three categories of goods, namely capital goods, intermediates and final goods, as recommended by the United Nations Department of Economic and Social Affairs (2007) (Table A.2). The share for each BEC category in total trade for the whole sample is illustrated in Table A.2 and the evolution over time of total trade for our three categories in shown in Figure 1.

Nominal GDP data are taken from the World Development Indicators database (WDI). To construct the bilateral exchange rates ${ }^{9}$ and the volatility measure, we use daily nominal middle exchange rates reported by DataStream from the WM Company/Reuters. ${ }^{10}$

Different measures of exchange rate volatility have been proposed in the related literature. Most approaches have in common that they measure the variance, but differ in the implementation. Examples are the standard deviation of the exchange rate or the moving standard deviation. Other measures, based on ARCH and GARCH models, have gained popularity among researchers in recent years. In particular, a GARCH models the variance of the disturbance term for each period as a function of the errors in the previous periods. All measures have 


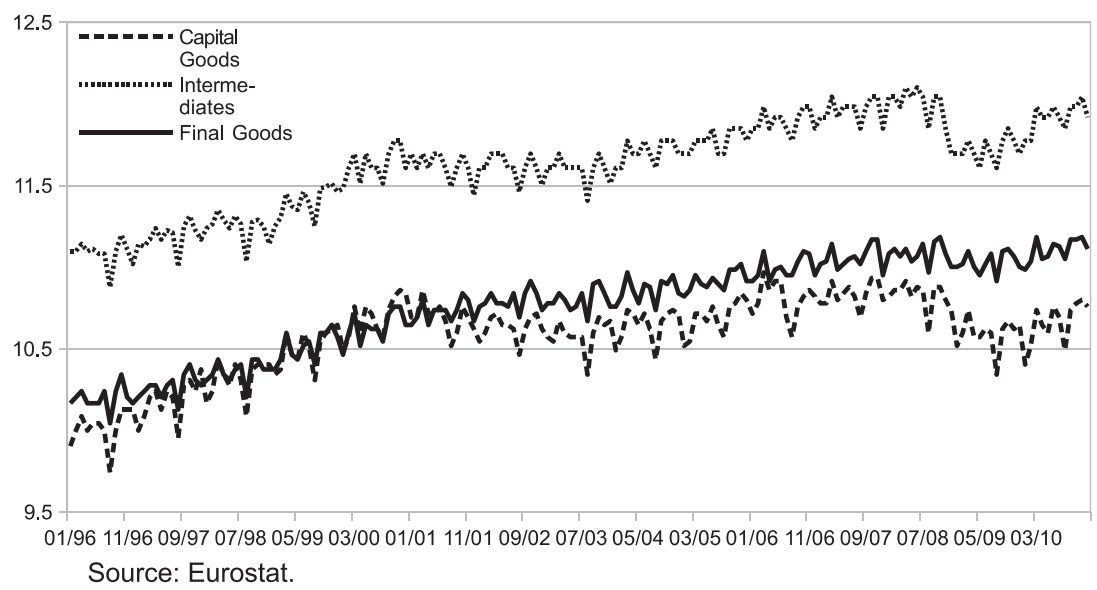

Figure 1. Monthly trade in capital, intermediate and final goods over time. Source: Eurostat.

drawbacks, like for instance the high persistence of real exchange rate shocks when moving average representations are applied, or low correlation in volatility when ARCH/GARCH models are used (Baum et al., 2004). The related literature on the impact of exchange rate volatility on trade shows that use of more sophisticated measures does not change the results (Corić and Pugh, 2010).

Another important question is whether the volatility of the nominal or the real exchange rate or both should be included in the model. An advantage of the real exchange rate is that it captures the true relative price of the good; however it also captures variation in the price levels, which is not desirable. Many studies use both exchange rates and compare the results. The differences they find are usually very small. ${ }^{11}$ Based on the recent literature, we have selected the standard deviation of the first difference of the logarithm of the nominal exchange rate, which has been used in various studies before (e.g. Clark et al., 2004):

$$
\text { Volatility }_{i j t}=\text { Std.dev. }\left[\ln \left(e_{i j t, d}\right)-\ln \left(e_{i j t-1, d}\right)\right] \quad d=1 \ldots 130
$$

where e denotes the daily bilateral exchange rate between countries $i$ and $j$ at business day, $d$. This measure has the advantage of being equal to zero when the exchange rate follows a consistent trend, which could be forecasted and consequently would not be a source of uncertainty.

To avoid biases steeming from changes in price levels via spurious correlation, we use nominal exchange rates. The measure is constructed as a short-term volatility measure with bilateral exchange rates from the past six months. Departing from most previous studies, we construct the exchange rate volatility measure with daily exchange rates, which allow for a more precise measure than 'end of the month' values, because exchange rates sometimes tend to suffer more extreme movements at the end of each month. High persistence of exchange rate shocks is not a problem, given that we only measure short-term volatility of the past six months with high frequency data. In contrast to studies investigating long-run volatility, we investigate the effect of short-term exchange rate volatility on trade by using a 6-month volatility measure. We assume that 6 months have 130 business days and thus construct the volatility measure accordingly.

Finally, corruption data are taken from the International Country Risk Guide (ICRG) published by the PRS Group and are a component of the Political Risk Dataset. It has a scale from zero (extremely high level of corruption) to six and assesses corruption within the political system. ${ }^{12}$

\section{MODEL SPECIFICATION AND MAIN RESULTS}

Estimations are conducted for the abovementioned BEC categories of products: capital goods, intermediate goods and consumption goods. These three groups differ significantly in terms of contracting patterns and hence the variables of interest might affect trade flows in a different direction and to a different extent. 


\subsection{Model specification}

First, we are estimating a gravity model of trade that incorporates the target integration and EU variables and incorporates the usual control variables and year-varying country fixed effects. The model is specified as,

$$
\begin{aligned}
& \ln X_{i j k t}= \beta_{0}+\beta_{1} \ln \left(Y_{i t} * Y_{j t}\right)+\beta_{2} \ln \text { Distance }_{i j}+\beta_{3} \text { EU }_{i j t}+\beta_{4} \text { Euro }_{i j t} \\
&+\beta_{5} \text { Border }_{i j}+\beta_{6} \text { Language }_{i j}+\beta_{7} \text { Landlocked }_{i j}+\beta_{8} \text { Island }_{i j} \\
&+\beta_{9} \text { Colony }_{i j}+\beta_{10} \text { Volatility }_{i j t}+\beta_{11} \ln \text { ExRate }_{i j t} \\
&+\beta_{12} \text { Corruption }_{i j t}+\kappa_{\kappa}+\lambda_{m}+\alpha_{i y}+\gamma_{j y}+\varepsilon_{i j k t}, \\
& \varepsilon_{i j k m}=\mu_{i j k}+\epsilon_{i j k t}
\end{aligned}
$$

where the explained variable $X_{\mathrm{ijkt}}$ denotes nominal exports in sector k from the reporter country $\mathrm{i}$ to the partner country $\mathrm{j}$ at time $t$ (month $\mathrm{m}$ in year $\mathrm{t}$ ). $\mathrm{Y}_{\mathrm{it}}$ and $\mathrm{Y}_{\mathrm{jt}}$ denote GDP of country $\mathrm{i}$ and $\mathrm{j}$, in year $\mathrm{t}$. Border, Language, Island and Colony are dummy variables that take the value of one when countries share a border, have a common official language, are islands or have ever had a colonial relationship. Landlocked is a dummy variable that takes the value of 1 if country $i$ does not have an exit to the sea, 2 if countries $i$ and $j$ are both landlocked and zero otherwise. The coefficients for these time-invariant variables cannot be directly obtained when the model is estimated adding bilateral-sectoral time-invariant (dyadic-sectoral: $\kappa_{i j k}$ ) fixed effects (not specified in equation (5)), which is the preferred specification.

Volatility denotes exchange rate volatility and is calculated using equation (4) and ExRate is the bilateral nominal exchange rate. Corruption is a discrete variable taking values in the range $0-6$, with higher values indicating less corruption. The independent variable $\kappa_{\mathrm{k}}$ controls for industry differences with dummy variables for each BEC category and $\lambda_{\mathrm{m}}$ controls for monthly seasonal effects with dummy variables for each month, $\mathrm{m}$. The yearvarying fixed effects $\alpha_{\mathrm{it}}$ and $v_{\mathrm{jt}}$ are proxies for multilateral resistance factors.

The simultaneous inclusion of the measure of nominal exchange rate volatility and the dummy variable for mutual Euro membership allows us to capture convex effects as described by Baldwin (2006). The variables are described in Table A.3.

Next, in order take into account the existence of zero trade flows we are following the two-stage approach proposed by Helpman et al. (2008). The first step estimation is a probit regression on the probability to export:

$$
\begin{aligned}
\operatorname{Pr}\left(X_{i j k t}=1\right)= & \Theta\left[\beta_{0}+\beta_{1} \ln \left(Y_{i t} * Y_{j t}\right)+\beta_{2} \ln \text { Distance }_{i j}+\beta_{3} \text { EU }_{i j t}+\beta_{4} \text { Euro }_{i j t}+\beta_{5} \text { Border }_{i j}\right. \\
& +\beta_{6} \text { Language }_{i j}+\beta_{7} \text { Landlocked }_{i j}+\beta_{8} \text { Island }_{i j}+\beta_{9} \text { Colony }_{i j}+\beta_{10} \text { Volatility }_{i j t} \\
& \left.+\beta_{11} \ln \text { ExRate }_{i j t}+\beta_{12} \text { Corruption }_{i j t}+\kappa_{\kappa}+\lambda_{m}+\alpha_{i}+\gamma_{j}\right] .
\end{aligned}
$$

The second step is estimated as a FE (with country-pair-sector fixed effects) regression including the linear prediction of exports down-weighted by its standard error (ZHAT) and the Inverse Mills Ratio (IMR). To fulfil the exclusion restriction, the variable corruption is excluded from the model. The specification is given by,

$$
\begin{aligned}
& \ln X_{i j k t}= \beta_{0}+\beta_{1} \ln \left(Y_{i t} * Y_{j t}\right)+\beta_{2} \ln \text { Distance }_{i j}+\beta_{3} \text { EU }_{i j t}+\beta_{4} \text { Euro }_{i j t}+\beta_{5} \text { Border }_{i j} \\
&+\beta_{6} \text { Language }_{i j}+\beta_{7} \text { Landlocked }_{i j}+\beta_{8} \text { Island }_{i j}+\beta_{9} \text { Colony }_{i j} \\
&+\beta_{10} \text { Volatility }_{i j t}+\beta_{11} \ln \text { ExRate }_{i j t} \\
&+\beta_{12} \text { ZHAT }+\beta_{13} \text { IMR }+\kappa_{\kappa}+\lambda_{m}+\alpha_{i t}+\gamma_{j t}+\varepsilon_{i j k t} \\
& \varepsilon_{i j k m}=\mu_{i j k}+\epsilon_{i j k t}
\end{aligned}
$$

where the included variables have been described below equation (5).

Equation (7) is estimated first with the typical time-invariant gravity controls (distance, common border, common language and so on) and second, with bilateral-sector fixed effects $\left(\kappa_{i j k}\right.$ instead of $\left.\kappa_{k}\right)$ and excluding the dyadic-time-invariant variables. In the latter case, coefficients for the time-invariant controls cannot be directly estimated, because their effect is subsumed in the fixed effects $\left(\mu_{i j k}\right)$ and also sectoral fixed effect cannot be added as controls. 


\subsection{Main results}

The extended gravity model is estimated for a sample of 35 countries over 15 years. Table 1 present the results obtained from estimating model (5) with dyadic-sectoral FE for capital goods, intermediates and final goods separately. ${ }^{13}$

The Euro effect on exports is negative for capital goods with estimates around -0.11 and positive for intermediates and final goods, with estimates around 0.09 and 0.06, respectively. In percentages, the Euro increase exports around $11 \%$ for intermediates and $9 \%$ for final goods. When excluding exchange rate volatility and exchange rate movements, the impact of the Euro on exports rises slightly (Columns 4-6, Table 1). The estimated coefficient for EU membership, which should give an idea of the effect of EU membership on the intensive margin, equals 0.11 for capital goods (Table 1, column 1), 0.09 for intermediate goods (Table 1, column 2), and 0.2 for final goods (Table 1, column 3). Hence, the highest EU effect is found for final goods.

Robust negative effects of the volatility measure on trade for the current period and for all the lags considered ${ }^{14}$ are observed. While for final goods (Table 1, column 3), the effect is higher for the current value of the volatility variable than for the past values, for capital goods (Table 1, column 1) lags of the volatility variable present higher coefficients than the current value. Finally, for intermediates (Table 1, column 2), the current value and the first lag show higher elasticities than the second and third lags.

Results in Table 2 are obtained using the Helpman et al. (2008) modelling strategy.

Columns 1, 3 and 5 show the first step results obtained from estimating equation (6). The results indicate that the probability to trade is negatively affected by the Euro adoption, with estimated coefficients that are slightly higher for capital goods $(-0.33)$ than for intermediates $(-0.26)$ and final goods $(-0.24)$. The results for the second step estimation are shown in columns 2, 4 and 6. The Euro effect is positive and significant for intermediate and final goods and slightly higher for the former, and negative for capital goods, similar to Table 1.

The results also show that mutual EU membership has a significant positive effect on the probability to trade as well as on the trade value for all types of goods. The coefficient of the EU dummy in the probit model is positive and statistically significant and range from 0.26 for capital goods and 0.34 for intermediates to 0.44 for final goods.

Table 1. Regression results for the baseline model (panel estimation)

\begin{tabular}{|c|c|c|c|}
\hline & Capital goods & Intermediates & Final goods \\
\hline Euro & $-0.114 * * *(0.0207)$ & $0.0942 * * *(0.0116)$ & $0.0648 * * *(0.00999)$ \\
\hline $\mathrm{EU}$ & $0.115 * * *(0.0161)$ & $0.0896 * * *(0.00902)$ & $0.202 * * *(0.0079)$ \\
\hline ln GDPs & $0.447 * * *(0.0395)$ & $0.682 * * *(0.0179)$ & $0.416 * * *(0.0152)$ \\
\hline Volatility & $-2.805 * * *(0.514)$ & $-2.435 * * *(0.285)$ & $-2.426 * * *(0.234)$ \\
\hline L1.Volatility & $-3.482 * * *(0.612)$ & $-2.560 * * *(0.339)$ & $-2.186 * * *(0.282)$ \\
\hline L2.Volatility & $-3.527 * * *(0.509)$ & $-1.865 * * *(0.282)$ & $-1.438 * * *(0.235)$ \\
\hline L3. Volatility & $-1.451 * * *(0.531)$ & $-0.617 * *(0.298)$ & $-0.968 * * *(0.247)$ \\
\hline ln ExRate & $-0.301 * * *(0.071)$ & $-0.0911 * *(0.0394)$ & $-0.276 * * *(0.0347)$ \\
\hline In L1.ExRate & $0.05(0.0634)$ & $0.0820 * *(0.0349)$ & $-0.0592 *(0.0311)$ \\
\hline In L2.ExRate & $0.271 * * *(0.0734)$ & $-0.0136(0.0409)$ & $0.0667 *(0.036)$ \\
\hline In L3.ExRate & $0.0826(0.0547)$ & $0.0191(0.0301)$ & $-0.0589 * *(0.0268)$ \\
\hline Corruption & $-0.0089 * * *(0.00308)$ & $0.00117(0.00169)$ & $0.0003(0.00149)$ \\
\hline Obs. & 283895 & 1045992 & 879509 \\
\hline$R^{2}$ & 0.194 & 0.113 & 0.167 \\
\hline RMSE & 1.171 & 1.243 & 1.006 \\
\hline
\end{tabular}

Note: HAC robust standard errors are in brackets. Significance levels:

$* 10 \%$,

$* * 5 \%$ and

*** $1 \%$; Reported $R^{2}$ is within $R^{2}$.

All models include dyadic-sectoral, monthly and origin-year, destination-year FE. L1-L3 denote the first, second and third lagged value of the corresponding variable. 


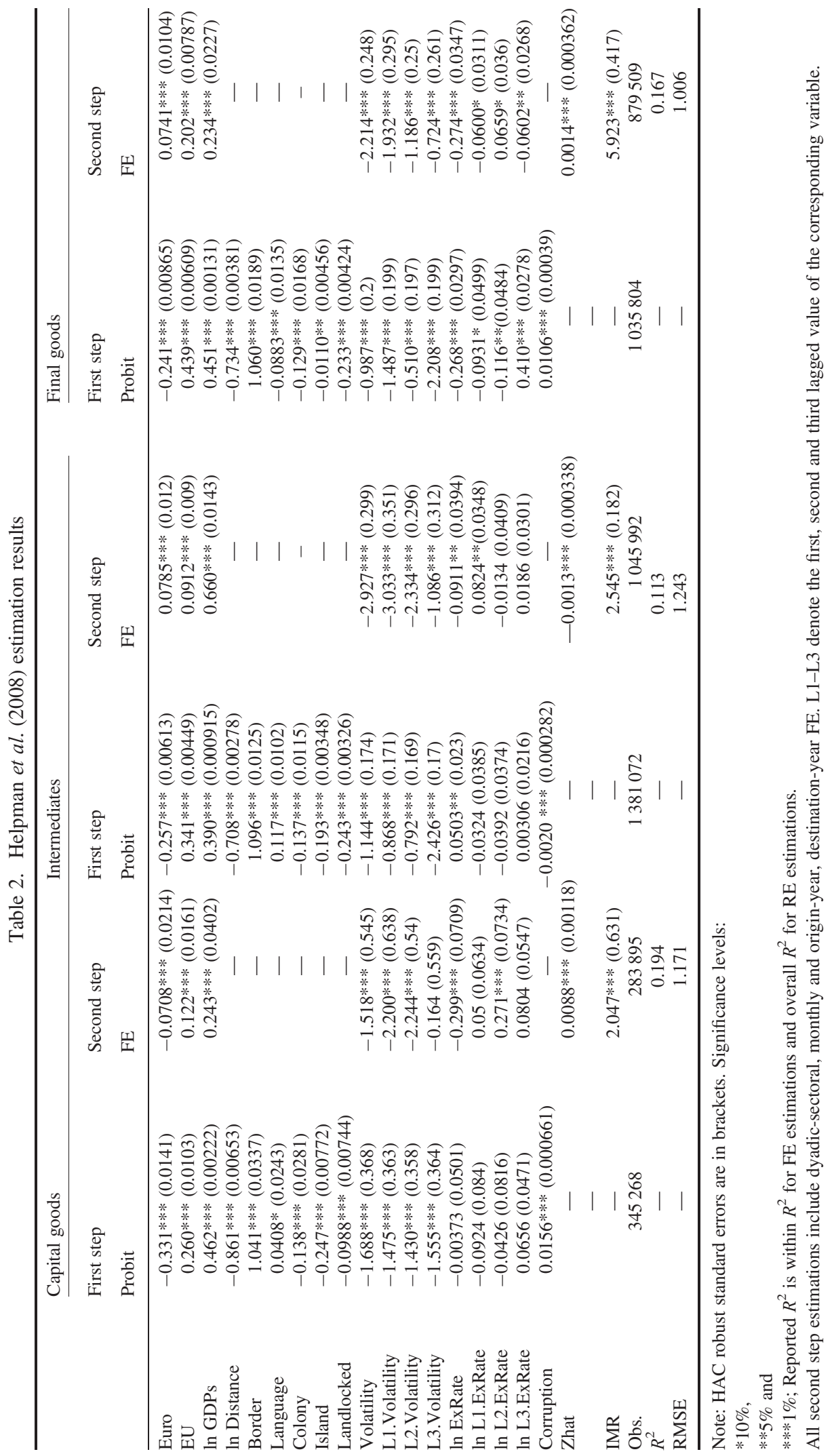


Table 3. Robustness checks

\begin{tabular}{|c|c|c|c|c|c|}
\hline \multirow{3}{*}{$\begin{array}{l}\text { Category of } \\
\text { goods\#: }\end{array}$} & (1) & (2) & (3) & (4) & (5) \\
\hline & \multicolumn{3}{|c|}{ Sample 1999-2010 } & \multicolumn{2}{|c|}{ Without big four } \\
\hline & 1 & 2 & 3 & 1 & 2 \\
\hline Euro & $-0.0761 * * *(0.0244)$ & $0.134 * * *(0.014)$ & $0.107 * * *(0.012)$ & $-0.103^{* * *}(0.0211)$ & $0.116^{* * *}(0.0127)$ \\
\hline EU & $0.130 * * *(0.0162)$ & $0.0958 * * *(0.00902)$ & $0.204 * * *(0.00797)$ & $0.0564 * * *(0.0165)$ & $0.078 * * *(0.0098)$ \\
\hline $\ln$ GDPs & $0.474 * * *(0.0134)$ & $0.529 * * *(0.0109)$ & $0.477 * * *(0.00954)$ & $0.448 * * *(0.0112)$ & $0.489 * * *(0.0096)$ \\
\hline In Distance & $-1.201 * * *(0.0554)$ & $-1.549 * * *(0.0499)$ & $-1.265^{* * *}(0.0437)$ & $-1.266^{* * *}(0.0482)$ & $-1.575 * * *(0.0473)$ \\
\hline Border & $0.601 * * *(0.0998)$ & $1.153 * * *(0.0897)$ & $0.860 * * *(0.079)$ & $0.539 * * *(0.0885)$ & $1.255 * * *(0.0869)$ \\
\hline Language & $0.193 *(0.115)$ & $0.103(0.104)$ & $0.152 *(0.0906)$ & $0.304 * * *(0.105)$ & $0.00207(0.104)$ \\
\hline Colony & $0.548 * * *(0.121)$ & $0.290 * * *(0.109)$ & $0.338 * * *(0.0959)$ & $0.172(0.122)$ & $0.247 * *(0.12)$ \\
\hline Island & $-0.815^{* * *}(0.199)$ & $-0.578 * * *(0.172)$ & $-0.156(0.152)$ & $0.149(0.186)$ & $0.104(0.167)$ \\
\hline Landlocked & $-1.510 * * *(0.264)$ & $-2.275 * * *(0.193)$ & $-1.116 * * *(0.169)$ & $-1.247 * * *(0.247)$ & $-1.575 * * *(0.191)$ \\
\hline Volatility & $-0.0637(0.764)$ & $-1.349 * * *(0.424)$ & $-1.162 * * *(0.341)$ & $-0.236(0.769)$ & $-1.024 * *(0.455)$ \\
\hline L1.Volatility & $-0.699(0.985)$ & $1.202 * *(0.55)$ & $-0.00509(0.443)$ & $-0.51(0.999)$ & $1.176 * *(0.596)$ \\
\hline L2.Volatility & $2.008 * *(1.007)$ & $0.0105(0.56)$ & $1.635 * * *(0.454)$ & $1.626(1.04)$ & $-0.682(0.616)$ \\
\hline L3.Volatility & $-0.547(0.753)$ & $0.153(0.415)$ & $-0.225(0.339)$ & $-0.48(0.795)$ & $0.970 * *(0.464)$ \\
\hline In ExRate & $0.878(0.582)$ & $-0.408(0.323)$ & $-0.195(0.286)$ & $0.363(0.655)$ & $-0.524(0.386)$ \\
\hline In L1.ExRate & $-3.464 * * *(1.255)$ & $0.645(0.694)$ & $-0.183(0.616)$ & $-2.301(1.445)$ & $0.699(0.851)$ \\
\hline In L2.ExRate & $3.299 * * *(1.179)$ & $0.00908(0.65)$ & $0.838(0.579)$ & $1.647(1.434)$ & $-0.133(0.846)$ \\
\hline In L3.ExRate & $-0.831 *(0.499)$ & $-0.256(0.274)$ & $-0.802 * * *(0.245)$ & $0.376(0.64)$ & $0.0121(0.378)$ \\
\hline Corruption & $-0.0083 * *(0.00332)$ & $0.00143(0.00184)$ & $0.00143(0.00164)$ & $0.0028(0.00345)$ & $0.007 * * *(0.0020)$ \\
\hline Year > 1998 & Yes & Yes & Yes & - & - \\
\hline USA & Yes & Yes & Yes & - & - \\
\hline Russia & Yes & Yes & Yes & - & - \\
\hline Japan & Yes & Yes & Yes & - & - \\
\hline China & Yes & Yes & Yes & - & - \\
\hline Turkey & Yes & Yes & Yes & Yes & Yes \\
\hline Obs. & 258383 & 950750 & 800811 & 226992 & 837354 \\
\hline$R^{2}$ & 0.694 & 0.619 & 0.68 & 0.719 & 0.649 \\
\hline RMSE & 1.186 & 1.254 & 1.026 & 1.112 & 1.249 \\
\hline
\end{tabular}

Note: Category 1 denotes capital goods, 2 intermediates and 3 consumption goods. HAC robust standard errors are in brackets. Significance levels:

$* 10 \%$

$* * 5 \%$ and

**** $1 \%$; Reported $R^{2}$ is the overall $R^{2}$.

Model (1) estimation with random effects. L1-L3 denote the first, second and third lagged value of the corresponding variable.

Thus, mutual EU membership increases the extensive margin of trade significantly, especially for industries producing final goods (Table 2, column 5). Also, the effect on the intensive margin stays positive and significant in the second step estimation with coefficients being slightly higher for capital and intermediate goods in comparison to the corresponding estimated in Table 1, where selection effects and firm heterogeneity where not considered. Meanwhile, the effect for final goods remains the same as in Table 1.

The excluded variable in the second stage, bilateral-corruption, which is expected to have an impact only on the probability to trade, but not on the value, performs considerably well. The measure has an insignificant impact on trade values (Table 1) and a significant impact on the probability to trade. Only for capital goods, the impact on the value traded is statistically significant, but very low.

In order to compare the magnitude of the effects of the exchange rate variables and the euro and EU effects beta coefficients have been computed (Table A.4 in the Appendix). The results indicate that the reduction of exchange rate volatility has a slightly stronger effect on trade in intermediate goods than the euro adoption, which implies complete elimination of this volatility, however the importance is reversed for final goods, for which the euro adoption has a clear stronger effect (almost twofold) than the reduction of exchange rate volatility. The same is the case for capital goods but to a lower extent. 
Table 3. Robustness checks

\begin{tabular}{|c|c|c|c|c|c|}
\hline \multirow[b]{3}{*}{$\begin{array}{l}\text { Category of } \\
\text { goods\#: }\end{array}$} & (6) & (7) & (8) & (9) & (10) \\
\hline & Without big four & \multicolumn{4}{|c|}{ Adding countries to sample (capital goods) } \\
\hline & 3 & 1 & 1 & 1 & 1 \\
\hline$\overline{\text { Euro }}$ & $0.068 * * *(0.0108)$ & $-0.104 * * *(0.0211)$ & $-0.103 * * *(0.0209)$ & $-0.105 * * *(0.0206)$ & $-0.0841 * * *(0.0208)$ \\
\hline EU & $0.136 * * *(0.0085)$ & $0.089 * * *(0.0165)$ & $0.119 * * *(0.0163)$ & $0.127 * * *(0.0161)$ & $0.129 * * *(0.0163)$ \\
\hline $\ln$ GDPs & $0.390 * * *(0.0084)$ & $0.477 * * *(0.0121)$ & $0.461 * * *(0.0119)$ & $0.460 * * *(0.0119)$ & $0.459 * * *(0.0129)$ \\
\hline ln Distance & $-1.315 * * *(0.0415)$ & $-1.246 * * *(0.0488)$ & $-1.222 * * *(0.0498)$ & $-1.217 * * *(0.0502)$ & $-1.297 * * *(0.0524)$ \\
\hline Border & $0.816^{* * *}(0.0766)$ & $0.501 * * *(0.0896)$ & $0.581 * * *(0.0888)$ & $0.603 * * *(0.09)$ & $0.492 * * *(0.0946)$ \\
\hline Language & $0.179 * *(0.0908)$ & $0.298 * * *(0.101)$ & $0.249 * *(0.102)$ & $0.213 * *(0.104)$ & $0.322 * * *(0.108)$ \\
\hline Colony & $0.143(0.106)$ & $0.363 * * *(0.113)$ & $0.543 * * *(0.108)$ & $0.533 * * *(0.109)$ & $0.819 * * *(0.117)$ \\
\hline Island & $1.210 * * *(0.147)$ & $-0.912 * * *(0.184)$ & $-1.034 * * *(0.185)$ & $-1.027 * * *(0.186)$ & $-1.293 * * *(0.193)$ \\
\hline Landlocked & $0.872 * * *(0.166)$ & $-2.123 * * *(0.248)$ & $-1.721 * * *(0.237)$ & $-1.655 * * *(0.235)$ & $-1.358 * * *(0.263)$ \\
\hline Volatility & $-0.968 * * *(0.355)$ & $-0.25(0.776)$ & $-0.452(0.738)$ & $-0.329(0.731)$ & $-0.154(0.748)$ \\
\hline L1.Volatility & $-0.277(0.465)$ & $-0.561(1.008)$ & $-1.59(0.97)$ & $-1.709 *(0.959)$ & $-1.744 *(0.987)$ \\
\hline L2.Volatility & $1.761 * * *(0.482)$ & $1.814 *(1.049)$ & $1.427(0.996)$ & $1.373(0.983)$ & $1.564(1.016)$ \\
\hline L3.Volatility & $0.436(0.365)$ & $-0.518(0.801)$ & $-0.807(0.746)$ & $-0.55(0.737)$ & $-0.555(0.76)$ \\
\hline In ExRate & $-0.0683(0.336)$ & $0.93(0.633)$ & $0.279(0.49)$ & $0.155(0.471)$ & $-0.0256(0.508)$ \\
\hline ln L1.ExRate & $-0.325(0.739)$ & $-2.837 * * *(1.399)$ & $-1.863 *(1.08)$ & $-1.632(1.041)$ & $-1.437(1.116)$ \\
\hline In L2.ExRate & $0.535(0.735)$ & $1.439(1.392)$ & $1.226(1.058)$ & $1.3(1.022)$ & $1.531(1.096)$ \\
\hline In L3.ExRate & $-0.448(0.329)$ & $0.549(0.621)$ & $0.249(0.466)$ & $0.0475(0.45)$ & $-0.386(0.485)$ \\
\hline Corruption & $0.012 * * *(0.0018)$ & $0.0023(0.0035)$ & $-0.00394(0.0033)$ & $-0.0058 *(0.0032)$ & $-0.0112 * * *(0.00311)$ \\
\hline Year > 1998 & - & - & - & - & - \\
\hline USA & - & Yes & Yes & Yes & Yes \\
\hline Russia & - & - & Yes & Yes & Yes \\
\hline Japan & - & - & - & Yes & Yes \\
\hline China & - & - & - & - & Yes \\
\hline Turkey & Yes & Yes & Yes & Yes & - \\
\hline Obs. & 702413 & 242764 & 256432 & 270343 & 270092 \\
\hline$R^{2}$ & 0.704 & 0.715 & 0.709 & 0.705 & 0.708 \\
\hline RMSE & 0.999 & 1.148 & 1.162 & 1.166 & 1.183 \\
\hline
\end{tabular}

All coefficients of the other variables included in the gravity equation show the expected signs. Estimates are always significant and positive for the GDP cross product and negative and significant for the distance between capitals (shown in Table 3, RE estimates).

Controls for common border always show significant positive estimates and the coefficient of the variable island is negative and significant. While the control variable for common official language shows mixed results, former colonial ties have a negative impact on the probability to export, but a positive on the value exported (Table 3).

A number of robustness indicates that the results are stable. We find that reducing the time period (Table 3, columns 1 to 3), or excluding economically big non-European countries (Table 3, columns 4 to 6) from the sample does not affect the results for the EU or Euro dummies. For the robustness we have chosen to present the random effects results, given that the coefficients of interest remain almost the same and in order to show as well the influence of the typical gravity variables, namely distance, common border, common language and colonial relationship. Nevertheless, the volatility variables lose significance and their general impact is less clear-cut. This is probably because of the fact that exchange rates in the full sample are more volatility before 1999 for countries that later joined the Euro and, in general, between EU-27 and countries with more or less free floating exchange rates like U.S., Russia or India. We also tried to estimate the model using Poisson Pseudo Maximum Likelihood suggested in the gravity literature (Santos Silva and Tenreyo, 2006; Head and Mayer, 2014) to accommodate zero trade flows. However, convergence could not be achieved in most cases when using the MRT, dyadic-sectoral and monthly dummy variables. Additionally, when convergence was achieved, the estimates were not stable to small changes in the specification. A similar problem was reported in Badinger and Türkcan (2014). 


\section{CONCLUSIONS AND POLICY IMPLICATIONS}

The main findings in this paper indicate that while mutual EU membership promotes trade through the extensive and intensive margin for most goods, Euro membership does so only via the intensive margin and not for capital goods. This could provide some evidence for a pronounced specialization-process taking place in the Euro zone at the industry level after the introduction of the Euro, which results in countries exporting goods from a lower number of industries, but with a higher value added. According to our results, the effect is slightly stronger for intermediate than for final goods. However, further research is needed to confirm this statement ideally using trade in value added.

The results for the extensive margin are in contrast to findings obtained by other authors (Bergin and Lin, 2012; Baldwin and Di Nino, 2006), who mostly found positive Euro effects on the extensive margin, but in line with Badinger and Türkcan (2014). In our study, this could be because of the product disaggregation and the monthly frequency of the trade data used. Negative effects on a monthly level do not necessarily mean that while the Euro forced a strong specialization process with pronounced seasonality on the industry level, the number of different products traded between members of the Euro zone on a yearly basis could have increased.

The introduction of controls for firm heterogeneity and sample selection bias does not change the results substantially. Nonetheless, extensive and intensive margin are affected very differently by our variables of interest. When dropping observations with higher volatility from the sample, the impact of exchange volatility on trade is less clear, while the impact of mutual EU and Euro membership remains robust.

Policy implications stemming from our results are manifold. Policymakers should keep in mind, that currency unions come at great costs with regard to the flexibility of the domestic monetary policy and positive trade effects may be very limited and do not exist for all types of goods. A fixed peg can also achieve the elimination of exchange rate volatility. Although we find a relatively small trade effect accruing from eliminating exchange rate variations, it still may be the best choice to avoid negative impacts as experienced currently in Euro zone and grants greater flexibility.

The question whether stabilizing the exchange rate is a desirable objective for policymakers is unclear and it is also unclear to which extent the real exchange rate is a variable that policymakers should be able to influence or actually can influence, besides establishing a currency union, a fixed peg or Dollarization (Eichengreen, 2007; Rodrik, 2008).

In light of the recent economic and current political crisis in Europe, our results provide evidence that a common currency may reduce investments and thus trade in capital goods within the currency union. Together with other imbalances, like current account imbalances or real exchange rate misalignments, this may lead to a loss in competitiveness that cannot be compensated by a devaluation of the domestic currency by a single member.

ACKNOWLEDGEMENT

Financial support from the Spanish Ministry of Economy and Competitiveness is grateful acknowledged (ECO2014-58991-C3-2-R).

\section{ENDNOTES}

1. Non significant Euro effects have been found when estimating the gravity model using pseudo-Poisson maximum likelihood (PPML) techniques without dyadic fixed effects, also in Glick and Rose (2015).

2. Baldwin (2006) provides a good overview on the early literature.

3. Other unpublished studies using product-level trade are Di Nino (2009) and Flam and Nordström, 2007.

4. An exception is Saia (2014) who uses a synthetic control approach to evaluate the cost of the United Kingdom of staying outside the Eurozone.

5. Namely China, India and Turkey.

6. We use of panel data techniques with country-pair-sector fixed effects to controls for time-invariant sources of endogeneity.

7. Data for Bulgaria, Cyprus, Czech Republic, Estonia, Hungary, Latvia, Luxembourg, Malta, Poland, Romania, Slovakia and Slovenia is missing for the years from 1996 to 1998.

8. A thorough description of the BEC classification is available from the United Nations Department of Economic and Social Affairs (2007).

9. The bilateral exchange rate measure is the average exchange rate of the past six months.

10. This rate is the midpoint between the bid rate and the offered rate.

11. A comprehensive comparison of the effects of real and nominal exchange rate volatility on exports was conducted by Cotter \& Bredin (2006) finding that magnitude and direction are not changing, while timing effects can be different.

12. In our dataset the cross-product for both countries ranges from 2 to 36. 
13. The results for the corresponding random effects model were very similar for the Euro effect: -0.10 for capital goods, 0.089 for intermediates and 0.068 for final goods. We report the FE because the Hausman test indicates that the error term is not orthogonal to the regressors in the RE model.

14. Exchange rate volatility and exchange rate movements are modelled using the current value and the first three lags to incorporate dynamic effects.

\section{APPENDIX}

Table A.1. List of countries and share in total trade

\begin{tabular}{|c|c|c|c|c|c|}
\hline \multicolumn{2}{|l|}{ Eurozone } & \multicolumn{2}{|c|}{ Other EU-Members } & \multicolumn{2}{|c|}{ Non-EU Members } \\
\hline Country-Year $(€)$ & Trade share $\%$ & Country & Trade share $\%$ & Country & Trade share $\%$ \\
\hline Austria (1999) & 87.07 & Bulgaria & 78.41 & Switzerland & 69.75 \\
\hline Belgium (1999) & 91.62 & Czech Republic & 93.51 & China & 15.80 \\
\hline Cyprus (2008) & 61.66 & Denmark & 83.75 & India & 19.60 \\
\hline Germany (1999) & 80.58 & Estonia (2011) & 91.73 & Japan & 13.36 \\
\hline Spain (1999) & 82.00 & United Kingdom & 82.91 & Norway & 72.39 \\
\hline Finland (1999) & 85.16 & Hungary & 88.48 & Russia & 32.52 \\
\hline France (1999) & 84.09 & Lithuania & 88.77 & Turkey & 49.57 \\
\hline Greece (2001) & 71.01 & Latvia & 90.86 & USA & 19.04 \\
\hline Ireland (1999) & 90.62 & Poland & 88.74 & & \\
\hline Italy (1999) & 80.78 & Romania & 85.09 & & \\
\hline Luxemburg (1999) & 96.18 & Sweden & 87.93 & & \\
\hline Malta (2008) & 64.49 & & & & \\
\hline Netherlands (1999) & 88.28 & & & & \\
\hline Portugal (1999) & 86.63 & & & & \\
\hline Slovakia (2009) & 93.69 & & & & \\
\hline Slovenia (2007) & 72.39 & & & & \\
\hline
\end{tabular}

Note: Figures are average shares of total trade value covered by our sample over 16 BEC categories and 15 years. Years in the first column indicate the year in which the euro was adopted.

Table A.2. List of products and corresponding BEC category

\begin{tabular}{llcc}
\hline BEC code & Description & Category & \% of total trade \\
\hline 111 & Food and beverages/primary/mainly for industry & 2 & 0.57 \\
112 & Food and beverages/primary/mainly for household consumption & 3 & 1.55 \\
121 & Food and beverages/processed/mainly for industry & 2 & 0.45 \\
122 & Food and beverages/processed/mainly for household consumption & 3 & 4.54 \\
210 & Industrial supplies n.e.s./primary & 2 & 2.07 \\
220 & Industrial supplies n.e.s./processed & 2 & 27.00 \\
310 & Fuels and lubricants/primary & - & 3.61 \\
321 & Fuels and lubricants/processed/motor spirit & 2 & 0.45 \\
322 & Fuels and lubricants/processed/other & 1 & 2.63 \\
410 & Capital goods (except transport equipment) & 2 & 14.32 \\
420 & Capital goods/parts and accessories & - & 9.21 \\
510 & Transport equipment and parts and accessories thereof/passenger motor cars & 1 & 3.68 \\
521 & Transport equipment and parts and accessories thereof/other/industrial & 3 & 0.43 \\
522 & Transport equipment and parts and accessories thereof/other/non-industrial & 2 & 7.39 \\
530 & Transport equipment and parts and accessories thereof/parts and accessor. & 3 & 3.32 \\
610 & Consumer goods n.e.s./durable & 3 & 4.93 \\
620 & Consumer goods n.e.s./semi-durable & 3 & 6.67 \\
630 & Consumer goods n.e.s./non-durable & - & 0.51 \\
700 & Goods not elsewhere specified & - & \\
\hline
\end{tabular}

Note: the percents are average figures for the whole period. Category 1 denotes capital goods, 2 intermediates and 3 consumption goods. 
Table A.3. Variable description and sources

\begin{tabular}{|c|c|c|}
\hline Variable & Description & Source \\
\hline $\ln X$ & $\begin{array}{l}\text { Log of monthly exports of good } k \text { from country } i \text { to } j \text { at month } m \text { of year } t \\
\text { in US\$ }\end{array}$ & Eurostat \\
\hline $\begin{array}{l}\ln \mathrm{GDPs}=\ln \\
\left(\mathrm{Y}_{\mathrm{it}} \times \mathrm{Y}_{\mathrm{jt}}\right)\end{array}$ & $\begin{array}{l}\text { Log of the cross-product of nominal GDP (Y) of the countries } i \text { and } j \text { at } \\
\text { year } t \text { in US\$ }\end{array}$ & CEPII \\
\hline ln Distance & Log of distance between capitals of country $\mathrm{i}$ and $\mathrm{j}$ in $\mathrm{km}$ & CEPII \\
\hline EU & $\begin{array}{l}\text { Dummy whether }(1) \text { or not }(0) \text { the countries } i \text { and } j \text { are both members of } \\
\text { the EU at time } t\end{array}$ & CIA World Factbook 2011 \\
\hline Euro & $\begin{array}{l}\text { Dummy whether ( } 1) \text { or not }(0) \text { the countries } i \text { and } j \text { have the Euro as a } \\
\text { common currency and time } t\end{array}$ & CIA World Factbook 2011 \\
\hline Border & $\begin{array}{l}\text { Dummy whether }(1) \text { or not }(0) \text { the countries } i \text { and } j \text { share a common } \\
\text { border }\end{array}$ & CEPII \\
\hline Language & $\begin{array}{l}\text { Dummy whether }(1) \text { or not }(0) \text { the countries } i \text { and } j \text { share a common } \\
\text { official language }\end{array}$ & CEPII \\
\hline Landlocked & $\begin{array}{l}\text { Dummy whether none }(0) \text {, one of the countries } i \text { and } j(1) \text {, or both (2) are } \\
\text { landlocked }\end{array}$ & CIA World Factbook 2011 \\
\hline Island & $\begin{array}{l}\text { Dummy whether none }(0) \text {, one of the countries } \mathrm{i} \text { and } \mathrm{j}(1) \text {, or both (2) are } \\
\text { on an island }\end{array}$ & CIA World Factbook 2011 \\
\hline Colony & Dummy whether $(1)$ or not $(0)$ the countries $i$ and $j$ ever had a colonial link & CEPII \\
\hline Volatility & $\begin{array}{l}\text { Bilateral volatility measure of the nominal exchange rate of the countries } i \\
\text { and } j \text { at month } m \text { of year } t\end{array}$ & WM Company/Reuters \\
\hline In ExRate & $\begin{array}{l}\text { Log of the bilateral nominal exchange rate of the countries } \mathrm{i} \text { and } \mathrm{j} \text { at a } \\
\text { given month } \mathrm{m} \text { of year } \mathrm{t}\end{array}$ & WM Company/Reuters \\
\hline Corruption & Cross-product of the corruption measure of countries $i$ and $j$ at year $t$ & $\begin{array}{l}\text { International Country Risk } \\
\text { Guide (ICRG) }\end{array}$ \\
\hline
\end{tabular}

Table A.4. Beta coefficients

\begin{tabular}{|c|c|c|c|c|c|c|}
\hline & \multicolumn{2}{|c|}{ Capital goods } & \multicolumn{2}{|c|}{ Intermediates } & \multicolumn{2}{|c|}{ Final goods } \\
\hline & $\mathrm{FE}$ & Second step FE & $\mathrm{FE}$ & Second step FE & $\mathrm{FE}$ & Second step FE \\
\hline Euro & -0.013 & -0.008 & 0.01 & 0.008 & 0.008 & 0.009 \\
\hline EU & 0.019 & 0.02 & 0.013 & 0.013 & 0.034 & 0.034 \\
\hline $\ln$ GDPs & 0.364 & 0.198 & 0.492 & 0.476 & 0.346 & 0.195 \\
\hline Volatility & -0.028 & -0.014 & -0.015 & -0.019 & -0.019 & -0.016 \\
\hline In ExRate & 0.107 & 0.106 & -0.004 & -0.002 & -0.343 & -0.345 \\
\hline Corruption & -0.021 & & 0.002 & & 0.001 & \\
\hline Zhat & & 0.028 & & -0.007 & & 0.007 \\
\hline IMR & & 0.005 & & 0.012 & & 0.009 \\
\hline
\end{tabular}

Note: Beta coefficients are calculated by standardizing the estimates from the regression analysis (Tables 1 and 2), so that the variances of both dependent and independent variables are one. They refer to how many standard deviations the explained variable will change per standard deviation increase in the corresponding explanatory variable.

\section{REFERENCES}

Anderson JE, Van Wincoop E. 2003. Gravity with gravitas: a solution to the border puzzle. American Economic Review 93(1): 170-192.

Badinger H, Türkcan K. 2014. Currency unions, export margins and product differentiation: an empirical assessment for European monetary union. Review of International Economics 22(1): 13-30.

Baldwin R. 2006. The Euro's trade effect. ECB Working Paper Series, 594.

Baldwin R, Di Nino V. 2006. Euros and zeros: the common currency effect on trade in New goods. NBER Working Paper Series, 12673.

Baum CF, Caglayan M, Ozkan N. 2004. Nonlinear effects of exchange rate volatility on the volume of bilateral exports. Journal of Applied Econometrics 19(1): 1-23.

Berger H, Nitsch V. 2008. Zooming out: the trade effect of the euro in historical perspective. Journal of International Money and Finance 27(8): 1244-1260. 
Bergin PR, Lin C-Y. 2012. The dynamic effects of currency union on trade. Journal of International Economics 87: 191-204.

Clark PB, Tamirisa N, Wei SJ. 2004. Exchange rate volatility and trade flows-some new evidence. International Monetary Fund Occasional Paper, No. 235.

Crozet M, Koenig P, Rebeyrol V. 2008. Exporting to insecure markets: a firm-level analysis. CEPII WP N $2008-13$.

Corić B, Pugh G. 2010. The effects of exchange rate variability on international trade: a meta-regression analysis. Applied Economics 42(20): 2631-2644.

Eichengreen B. 2007. The real exchange rate and economic growth. Commission on Growth and Development Working Paper, 4. World Bank.

Eicher TS, Henn C. 2011. One money, one market: a revised benchmark. Review of International Economics 19(3): 419-435.

Flam H, Nordström H. 2007. Explaining large euro effects on trade: the extensive margin and vertical specialization. Manuscript, Institute for International Economic Studies, Stockholm University.

Frankel J. 2008. The estimated effects of the euro on trade: why are they below historical effects of monetary unions among smaller countries? NBER Working Papers, 14542.

Frankel J, Rose AK. 2002. An estimate of the effect of common currencies on trade and income. The Quarterly Journal of Economics 117(2): 437-466.

Glick R, Rose AK. 2002. Does a currency union affect trade? The time-series evidence. European Economic Review 46(6): $1125-51$.

Head, K., T. Mayer, 2014. Gravity equations: workhorse, toolkit, and cookbook. In G. Gopinath, E. Helpman, K. Rogoff (eds.) Handbook of international economics, 4, Amsterdam: Elsevier-North Holland.

Helpman E, Melitz M, Rubinstein Y. 2008. Estimating trade flows: trading partners and trading volumes. The Quarterly Journal of Economics 123(2): 441-487.

Martínez-Zarzoso I. 2013. The log of gravity revisited. Applied Economics 45(3): 311-327.

Melitz MJ. 2003. The impact of trade on intra-industry reallocations and aggregate industry productivity. Econometrica 71(6): $1695-1725$.

Rodrik D. 2008. The real exchange rate and economic growth. Brookings Papers on Economic Activity, Fall $2008,365-439$.

Rose AK. 2000. One money, one market: estimating the effect of common currencies on trade. Economic Policy 15(30): 7-46.

Rose-Ackerman S. 1999. Corruption and Government: Causes, Consequences, and Reform, Cambridge University Press: Cambridge. United Kingdom.

Santos Silva JMC, Tenreyro S. 2010. Currency unions in prospect and retrospect. Annual Review of Economics 2(1): 51-74.

Saia A. 2014. Choosing the Open Sea: The Cost to the UK of Staying Out of the Euro, University of Bologna: Mimeo.

Santos Silva JMC, Tenreyo S. 2006. The log of gravity. Review of Economics and Statistics 88: 641-658.

Tinbergen J. 1962. Shaping the World Economy; Suggestions for an International Economic Policy, Twentieth Century Fund: New York.

United Nations Department of Economic and Social Affairs. 2007. Future revision of the Classification by Broad Economic Categories (BEC). 